\title{
Penerapan Personal Protective Equipment Pada Workshop Politeknik Ilmu Pelayaran Makassar
}

\author{
Syahrisal $^{1, \mathrm{a}}$, Paulus Pongkessu ${ }^{1}$, Mahadir Sirman ${ }^{1, \mathrm{~b}}$ dan Heny Pasandang Nari ${ }^{1}$ \\ 1,2,3 Jurusan Teknik Mesin, Politeknik Ilmu Pelayaran, Makassar 90712, Indonesia \\ *syahrisal.pipmks@gmail.com
}

\begin{abstract}
Implementation according to the rules of occupational safety and health is needed in all jobs that are useful to avoid things that are not desirable, such as work accidents. The workforce consists of educated and trained people. One of the educated people referred to is the D-IV and DP-III graduates of the Makassar Shipping Polytechnic, because one of the fillers in the world of work is the Polytechnic graduate. The learning process while in the laboratory must be a serious concern in order to get qualified prospective workers, especially understanding about the application of occupational safety and health (K3) especially the use of personal protective equipment so that there are no direct or indirect obstacles in the work, such as work accidents occur, damage to machinery, cessation of production processes, environmental damage and expenses related to work accidents. The purpose of this research is to find out the availability and analyze the application of personal protective equipment to occupational safety and health in the workshop. This research includes the type of survey research with quantitative methods. This design seeks to determine the PPE facilities available at the Workshop, symbols / cues about occupational safety and health, the conditions of the practice room and what percentage of PPE use by cadets during practice. The data collection method is done by using a questionnaire and documentation used to determine PPE facilities available in the Workshop, symbols / cues about occupational safety and health, the conditions of the practice room and what percentage of the use of PPE cadets during practice. The conclusion is that the personal protective equipment (PPE) facilities in the workshop have been provided by the workshop and can be used by cadets or pasis and safely in accordance with government regulations, and the knowledge, understanding and application of cadets towards PPE have reached an average of $95 \%$
\end{abstract}

Keywords: PPE; Student;K3, Workshop

\begin{abstract}
Abstrak: Penerapan sesuai aturan keselamatan dan kesehatan kerja sangat dibutuhkan pada semua pekerjaan yang berguna untuk menghindari hal-hal yang tidak diinginkan, misalnya kecelakaan kerja. Para tenaga kerja terdiri dari orang-orang terdidik dan terlatih. Orang-orang terdidik yang dimaksud salah satunya adalah lulusan D-IV dan DPIII Politeknik Ilmu Pelayaran Makassar, karena salah satu pengisi tenaga kerja di dunia kerja adalah lulusan Politeknik, maka proses pembelajaran selama di laboratorium harus menjadi perhatian yang serius guna mendapatkan calon tenaga kerja yang berkualitas, khususnya memahami tentang penerapan pelaksanaan keselamatan dan kesehatan kerja (K3) khususnya pemakaian alat pelindung diri sehingga tidak terjadi hambatanhambatan langsung maupun tidak langsung dalam pekerjaan, seperti halnya terjadi kecelakaan kerja, kerusakan mesin, terhentinya proses produksi, kerusakan lingkungan dan pengeluaran-pengeluaran biaya kecelakaan kerja. Tujuan dari hasil penelitian ini adalah untuk mengetahui ketersediaan dan menganalisa penerapan personal protective equipment terhadap keselamatan dan kesehatan kerja di workshop. penelitan ini termasuk jenis penelitian survey dengan metode kuantitatif. Desain ini berupaya untuk mengetahui fasilitas APD yang tersedia di Workshop, symbol-simbol/isyarat tentang keselamatan dan kesehatan kerja, kondisi ruang praktek dan berapa besar persentase penggunaan APD oleh taruna selama praktek. Adapun metode pengambilan data dilakukan dengan menggunakan angket dan dokumentasi yang digunakan untuk mengetahui fasilitas APD yang tersedia di Workshop, simbol-simbol tentang keselamatan dan kesehatan kerja, kondisi ruang praktek dan berapa besar persentase penggunaan APD taruna selama praktek. Adapaun kesimpulan adalah fasilitas alat pelindung diri (APD) di workshop telah disediakan oleh pihak workshop dan dapat digunakan oleh taruna ataupun pasis dan dengan aman sesuai dengan yang dipersyaratkan peraturan pemerintah, dan pengetahuan, pemahaman dan penerapan taruna terhadap APD sudah mencapai rerata $95 \%$.
\end{abstract}

Kata kunci : APD; Taruna; K3, Workshop

\section{PENDAHULUAN}

Pada saat sekarang ini, sebagaian besar tenaga kerja di seluruh dunia diperkirakan bekerja dalam kondisi yang tidak aman sehingga dapat mengganggu kesehatan para pekerja tersebut. Di Indonesia, angka kecelakaan kerja menunjukkan angka yang sangat mengkhawatirkan. Bahkan menurut 
penelitian International Labor Organization (ILO), Indonesia menempati urutan ke 52 dari 53 negara dengan manajemen K3 yang buruk. Padahal biaya yang akan dikeluarkan oleh perusahaan akan sangat besar apabila sampai terjadi kecelakaan di tempat kerja [1].

Menurut data International Labor Organization (ILO) pada tahun 2010 tercatat setiap tahunnya lebih dari 2 juta orang yang meninggal akibat kecelakaan dan penyakit akibat kerja. Sekitar 160 juta orang menderita penyakit akibat kerja dan 270 juta kasus kecelakaan kerja pertahun diseluruh dunia [2,3]. Hal ini mengindikasikan masih rendahnya aspek keselamatan dan kesehatan kerja di Indonesia atau bisa dikatakan bahwa keselamatan dan kesehatan kerja belum mendapat perhatian dan menjadi budaya di tengah masyarakat Indoensia.

Surat kabar harian Kompas, terbitan 17 September 2002 menyebutkan bahwa selama tahun 2000 tercatat 66.367 kasus kecelakaan kerja dengan korban meninggal 4.142 orang di Indonesia. Makalah yang disampaikan oleh Astrid Sulistomo pada seminar K3RS tahun 2001 lalu mengatakan bahwa berdasarkan data yang diperolah ILO, setiap tahun terjadi 1,1 juta kematian yang disebabkan oleh penyakit akibat kerja atau kecelakaan akibat hubungan pekerjaan. Dari jumlah tersebut, 354.000 orang mengalami kecelakaan fatal. Dan dari 250 juta kecelakaan, sekitar 300.000 terjadi kematian, sementara sisanya adalah kematian karena penyakit akibat hubungan pekerjaan baru setiap tahunnya. Kejadian kecelakaan walau sekecil apapun tidak boleh dipandang remeh, sebab apabila kita telusuri lebih jauh dampak yang ditimbulkannya maka akan lebih banyak ditemukan kerugian lainnya. Layaknya gunung es yang tampak hanya kecil, tetapi di dasarnya sangat besar. Pemerintah dalam hal ini melalui Permenaker No. PER 05/ MEN/ 1996 mengeluarkan peraturan penerapan Sistem Manajemen Keselamatan dan Kesehatan Kerja atau SMK3 bagi industri di indonesia dalam menghadapi tantangan globalisasi.

Kejadian serupa pun pernah terjadi di workshop dimana saat itu adalah pelaksanaan ujian Negara sekitar tahun 2000an, salah seorang peserta ujian praktek Perbengkelan pada saat praktek mengalami kecelakaan dimana lengan baju kerja (wear pack) terlilit pada mesin bubut yang mengakibatkan tangan dari peserta memerah/luka (Tim workshop: 2000). Kejadian lain di tahun yang sama salah seorang staf bengkel mengalami kecelakaan kerja (kuku tangan terlepas dari jarinya) akibat memutar handle mesin las generator dengan tidak menggunakan sarung tangan (Tim workshop : 2000). Dan kejadian yang terbaru di tahun 2019 ini salah seorang tehnisi workshop juga mengalami kecelakaan kerja (kuku kaki terlepas dari jarinya) akibat tidak menggunakan sepatu safety saat mengangkat besi (Tim workshop : 2019).

Meskipun ketentuan mengenai kesehatan dan keselamatan kerja telah diatur sedemikian rupa, tetapi dalam praktiknya tidak seperti yang diharapkan. Begitu banyak faktor di lapangan yang mempengaruhi kesehatan dan keselamatan kerja seperti manusia, lingkungan dan psikologis.

Menurut Undang-undang Keselamatan dan Kesehatan Kerja (K3) tahun 1970 Personal Protective Equipment (Alat Pelindung Diri) adalah wajib dipakai oleh operator saat melakukan pengerjaan di laboratorium. Alat pelindung diri adalah merupakan bagian penting dalam penerapan Keselamatan dan Kesehatan Kerja dalam laboratorium. Kecelakan kerja bisa terjadi jika tidak memperhatikan prinsip "Unsave condition and unsave action". Kecelakaan kerja dapat menyebabkan sakit, cacat, kerusakan mesin, terhentinya proses produksi, kerusakan lingkungan dan pengeluaran-pengeluaran biaya kecelakaan kerja. Secara umum kecelakaan kerja terjadi karena 2 (dua) hal penyebab yaitu keadaan lingkungan yang tidak aman dan tindak perbuatan manusia yang tidak memenuhi keselamatan dan kesehatan kerja.

Penerapan sesuai aturan keselamatan dan kesehatan kerja sangat dibutuhkan pada semua pekerjaan yang berguna untuk menghindari hal-hal yang tidak diinginkan, misalnya kecelakaan kerja. Para tenaga kerja terdiri dari orang-orang terdidik dan terlatih. Orang-orang terdidik yang dimaksud salah satunya adalah lulusan D-IV dan DP-III Politeknik Ilmu Pelayaran Makassar, karena salah satu pengisi tenaga kerja di dunia kerja adalah lulusan Politeknik, maka proses pembelajaran selama di 


\section{Syahrisal, Paulus Pongkessu, Mahadir Sirman, Heny Pasandang Nari. Penerapan Personal Protective}

Equipment Pada Workshop Politeknik Ilmu Pelayaran Makassar

laboratorium harus menjadi perhatian yang serius guna mendapatkan calon tenaga kerja yang berkualitas, khususnya memahami tentang penerapan pelaksanaan keselamatan dan kesehatan kerja (K3) khususnya pemakaian alat pelindung diri sehingga tidak terjadi hambatan-hambatan langsung maupun tidak langsung dalam pekerjaan, seperti halnya terjadi kecelakaan kerja, kerusakan mesin, terhentinya proses produksi, kerusakan lingkungan dan pengeluaran-pengeluaran biaya kecelakaan kerja [4].

Tujuan dari hasil penelitian ini adalah untuk mengetahui ketersediaan dan menganalisa penerapan personal protective equipment terhadap keselamatan dan kesehatan kerja di workshop.

\section{METODE PENELITIAN}

\section{A. Tempat dan Waktu Penelitian}

Penelitian ini dilaksanakan di workshop Politeknik Ilmu Pelayaran Makassar (Kampus I). Adapun waktu pelaksanaannya dimulai bulan April sampai dengan bulan Mei 2019

\section{B. Metode Penelitian}

Berdasarkan rumusan masalah yang telah dijelaskan, maka penelitan ini termasuk jenis penelitian survey dengan metode kuantitatif. Desain ini berupaya untuk mengetahui fasilitas APD yang tersedia di Workshop, symbol-simbol/isyarat tentang keselamatan dan kesehatan kerja, kondisi ruang praktek dan berapa besar persentase penggunaan APD oleh taruna selama praktek.

Menurut Arikunto [5] populasi adalah keseluruhan dari subjek penelitian. Jadi yang dimaksud populasi adalah individu yang memiliki sifat yang sama walaupun prosentase kesamaan itu sedikit, atau dengan kata lain seluruh individu yang akan dijadikan sebagai objek penelitian. Populasi dalam penelitian ini meliputi taruna Diploma IV Semester Dua (II) yang sedang mengikuti kegiatan praktek Mata Kuliah Penggunaan Peralatan Kerja Manual dan Bertenaga di kampus I sebanyak kurang lebih 260 orang dari 11 kelas Jurusan Teknika (Prodi Teknika PIP Mks, 2019). Metode pengambilan sampel dilakukan secara purposive sampling. [6] menjelaskan bahwa Sampling Purposive adalah teknik penentuan sampel dengan pertimbangan tertentu. Menurut [5], Penentuan pengambilan sampel sebagai berikut : Apabila kurang dari 100 lebih baik diambil semua hingga penelitiannya merupakan penelitian populasi. Jika jumlah subjeknya besar dapat diambil antara $10-15 \%$ atau $20-25 \%$ atau lebih tergantung sedikit banyaknya.

Adapun metode pengambilan data dilakukan dengan menggunakan angket dan dokumentasi yang digunakan untuk mengetahui fasilitas APD yang tersedia di Workshop, symbol-simbol/isyarat tentang keselamatan dan kesehatan kerja, kondisi ruang praktek dan berapa besar persentase penggunaan APD taruna selama praktek.

Angket/kuesioner tentang persentase pengunaan APD taruna selama praktek ini dibuat dengan memberi pertanyaan-pertanyaan sesuai dengan indikator-indikator yang telah dikembangkan. Pertanyaan ini dimodifikasi dengan beberapa jenis pertanyaan yang dibuat dalam beberapa kolom pertanyaan. Hal ini dilakukan untuk mengetahui layak atau tidak instrumen digunakan untuk mencapai tujuan penelitian. Uji coba instrumen yang dimaksud adalah uji coba terhadap instrumen angket yang digunakan untuk pengumpulan data.

\section{HASIL DAN PEMBAHASAN}

\section{A. Hasil dan Analisis Data}

Data dalam penelitian ini mencakup data tentang jumlah, penggunaan, fungsi peralatan, kondisi ruang praktek, apakah peralatan sesuai kebutuhan atau jumlah peserta praktikum, serta bagaimana penerapannya di lapangan. Data dikumpulkan melalui pembagian kuesioner kepada 66 (enam puluh enam) orang taruna semester II (Dua) dari 11 Kelas.

Untuk mendapatkan data yang benar-benar valid dan sesuai dengan pengetahuan, pemahaman taruna dan penerapannya serta kondisi yang ada di lapangan (workshop), maka diperlukan kuesioner atau angket yang berisi pertanyaan-pertanyaan (kolom A-H) yang dibagi dalam beberapa instrument 
pengumpul data. Instrumen ini diajukan kepada taruna dalam bentuk angket/kuesioner kemudian dikembangkan berdasarkan indikator penelitian sehingga benar-benar dapat menggali sejumlah data yang diperlukan.

Beikut ini disajikan tabel jawaban dari kuesioner/angket yang telah dibagikan kepada beberapa taruna yang dijadikan sampel (66 orang) yang mengacu pada beberapa pertanyaan-pertanyaan yang diajukan kepada mereka sesuai yang telah disebutkan pada bab sebelumnya (Bab III).

Tabel 1 Persentase jawaban yang digunakan untuk mengetahui atau memahami tentang APD sebelum digunakan.

\begin{tabular}{|c|c|c|c|}
\hline \multirow{2}{*}{ NO } & \multirow{2}{*}{ KOLOM A } & \multicolumn{2}{|c|}{ Jawaban } \\
\hline & & Ya & Tidak \\
\hline 1 & Apakah anda mengetahui apa yang dimaksud dengan Alat Pelindung Diri (APD) ? & $100 \%$ & \\
\hline 2 & Apakah dengan memakai APD akan berguna pada waktu anda praktek ? & $100 \%$ & \\
\hline 3 & $\begin{array}{l}\text { Apakah Kegunaan APD menurut anda? } \\
\text { a. Untuk menjaga kesehatan dan keamanan kerja } \\
\text { b. Untuk melindungi tubuh dari cedera dan sakit } \\
\text { c. Tidak tahu }\end{array}$ & \multicolumn{2}{|c|}{$\begin{array}{c}70 \% \\
30 \% \\
0 \%\end{array}$} \\
\hline 4 & $\begin{array}{l}\text { Apa akibatnya apabila anda tidak menggunakan APD? } \\
\text { a. Pekerjaan tidak dapat dilaksanakan dengan baik } \\
\text { b. Bisa menimbulkan kecelakaan dan gangguan kesehatan } \\
\text { c. Tidak tahu }\end{array}$ & \multicolumn{2}{|c|}{$\begin{array}{c}5 \% \\
95 \% \\
0 \%\end{array}$} \\
\hline
\end{tabular}

Tabel 2. Jawaban yang digunakan tentang kondisi workshop

\begin{tabular}{|c|l|c|c|}
\hline \multirow{2}{*}{ NO } & \multicolumn{1}{|c|}{ KOLOM B } & \multicolumn{2}{|c|}{ Jawaban } \\
\cline { 3 - 4 } & \multicolumn{1}{|c|}{ Ya } & Tidak \\
\hline 1 & $\begin{array}{l}\text { Apakah kondisi ruangan praktek di worshop mendukung terciptanya keselamatan } \\
\text { dan kesehatan kerja (K3)? }\end{array}$ & $100 \%$ & $100 \%$ \\
\hline 2 & $\begin{array}{l}\text { Apakah di workshop tersedia poster/gambar yang mengingatkan tentang } \\
\text { keselamatan dan kesehatan kerja (K3)? }\end{array}$ & $\begin{array}{l}\text { yang rusak diganti, } \\
\text { penga-daan yang } \\
\text { baru } \\
\text { diutamakan ? }\end{array}$ \\
\hline
\end{tabular}

Tabel 3 Jawaban yang digunakan untuk pemahaman serta tindakan saat penggunaan APD

\begin{tabular}{|c|l|c|}
\hline NO & \multicolumn{1}{|c|}{ KOLOM C } & Jawaban \\
\hline 1 & Apa alasan anda menggunakan APD saat praktek ? & $5 \%$ \\
& a. Takut kena sanksi jika tidak memakai APD & $95 \%$ \\
& b. Untuk melindungi diri dari bahaya atau kecelakaan kerja & $0 \%$ \\
\hline 2 & c. Ikut-ikutan saja karena teman kerja yang lain menggunakan APD & \\
& Apa alasan anda tidak menggunakan APD saat praktek? & $20 \%$ \\
& a. APD tidak nyaman dipakai & $75 \%$ \\
& b. APD tidak tersedia & $5 \%$ \\
\hline 3 & c. Sudah terbiasa tidak memakai APD & \\
& Bagaimana sikap anda jika workshop tidak menyediakan APD di tempat praktek? & $5 \%$ \\
& a. Menolak untuk bekerja & $95 \%$ \\
& b. Tidak bekerja sambil menunggu APD disediakan oleh workshop & $0 \%$ \\
\hline
\end{tabular}


222 Syahrisal, Paulus Pongkessu, Mahadir Sirman, Heny Pasandang Nari. Penerapan Personal Protective Equipment Pada Workshop Politeknik Ilmu Pelayaran Makassar

Tabel 4.4 Persentase Jawaban pengetahuan dan tanggapan tentang APD

\begin{tabular}{|c|c|c|c|}
\hline \multirow{2}{*}{ NO } & \multirow{2}{*}{ KOLOM D } & \multicolumn{2}{|c|}{ Jawaban } \\
\hline & & Ya & Tidak \\
\hline 1 & $\begin{array}{l}\text { Apakah workshop telah menyediakan APD sesuai dengan resiko bahaya dan } \\
\text { jenis pekerjaan saat praktek? }\end{array}$ & $95 \%$ & $5 \%$ \\
\hline 2 & Apakah APD tersebut mudah didapatkan? & $90 \%$ & $10 \%$ \\
\hline 3 & Apakah APD yang tersedia cukup untuk semua praktikum ? & $70 \%$ & $30 \%$ \\
\hline 4 & Apakah disediakan tempat untuk menyimpan APD & $80 \%$ & $20 \%$ \\
\hline 5 & $\begin{array}{l}\text { Jenis APD apa yang anda gunakan saat praktek mengelas? (Jawaban bisa lebih } \\
\text { dari } 1 \text { (satu) } \\
\text { a. Safety Helmet } \\
\text { b. Ear Plug } \\
\text { c. Masker mulut } \\
\text { d. Topeng Las } \\
\text { e. Gloves (sarung tangan) } \\
\text { f. Pakaian Las } \\
\text { g. Wear Pack } \\
\text { h. Apron } \\
\text { i. Safety Shoes }\end{array}$ & \multicolumn{2}{|c|}{$\begin{array}{l}\text { Rata-rata } 5 \text { Jenis } \\
\text { APD yang mereka } \\
\text { gunakan }\end{array}$} \\
\hline 6 & $\begin{array}{l}\text { Jenis APD apa yang anda gunakan saat praktek membubut? (Jawaban bisa lebih } \\
\text { dari } 1 \text { (satu) } \\
\text { a. Safety Helmet } \\
\text { b. Ear Plug } \\
\text { c. Masker mulut } \\
\text { d. Googles (kacamata) } \\
\text { e. Gloves (sarung tangan) } \\
\text { f. Wear Pack } \\
\text { g. Safety Shoes } \\
\text { Menurut anda, siapa yang wajib merawat APD yang telah disediakan oleh } \\
\text { institusi? } \\
\text { a. Pihak workshop } \\
\text { b. Setiap praktikum } \\
\text { c. Tidak tahu }\end{array}$ & \multicolumn{2}{|c|}{$\begin{array}{l}\text { Rata-rata } 5 \text { Jenis } \\
\text { APD yang mereka } \\
\text { gunakan }\end{array}$} \\
\hline
\end{tabular}

Tabel 4.5 Persentase Jawaban pertanyaan kepuasan \& tanggapan tentang penggunaan APD

\begin{tabular}{|c|c|c|c|}
\hline \multirow{2}{*}{ NO } & \multirow{2}{*}{ KOLOM E } & \multicolumn{2}{|c|}{ \% Jawaban } \\
\hline & & $\mathrm{Ya}$ & Tidak \\
\hline 1 & Apakah selama praktek anda merasa nyaman menggunakan APD? & $95 \%$ & $5 \%$ \\
\hline 2 & Apakah APD tersebut telah sesuai dengan kebutuhan perlindungan diri anda? & $95 \%$ & $5 \%$ \\
\hline 3 & Apakah APD tersebut mengganggu aktivitas anda? & $5 \%$ & $95 \%$ \\
\hline 4 & Apakah APD tersebut menimbulkan bahaya tambahan? & $5 \%$ & $95 \%$ \\
\hline
\end{tabular}

Tabel 4.6 Persentase Jawaban pertanyaan pemahaman tentang aturan kerja

\begin{tabular}{|c|l|c|c|}
\hline NO & \multicolumn{1}{|c|}{ KOLOM F } & \multicolumn{2}{c|}{$\%$ Jawaban } \\
\cline { 2 - 4 } & \multicolumn{1}{|c|}{ Ya } & Tidak \\
\hline 1 & $\begin{array}{l}\text { Apakah di workshop terdapat peraturan yang mewajibkan setiap taruna untuk } \\
\text { menggunakan APD? }\end{array}$ & $95 \%$ & $5 \%$ \\
\hline 2 & $\begin{array}{l}\text { Jika ada, apakah peraturan itu sudah diketahui oleh semua taruna yang praktek di } \\
\text { workshop? }\end{array}$ & $95 \%$ & $5 \%$ \\
\hline 3 & $\begin{array}{l}\text { Apakah dengan peraturan tersebut keselamatan dan kesehatan anda menjadi lebih } \\
\text { baik? }\end{array}$ & $95 \%$ & $5 \%$ \\
\hline 4 & Apakah workshop pernah mengadakan pelatihan K3 khusunya tentang APD? & $40 \%$ & $60 \%$ \\
\hline
\end{tabular}


Tabel 4.7 Jenis pertanyaan pemahaman tentang pengawasan kerja

\begin{tabular}{|c|c|c|c|}
\hline \multirow{2}{*}{ NO } & \multirow{2}{*}{ KOLOM G } & \multicolumn{2}{|c|}{ \% Jawaban } \\
\hline & & $\mathrm{Ya}$ & Tidak \\
\hline 1 & Apakah perlu diadakan pengawasan penggunaan APD? & $90 \%$ & $10 \%$ \\
\hline 2 & Apakah selama anda praktek di workshop adakah pengawasan tersebut? & $90 \%$ & $10 \%$ \\
\hline 3 & $\begin{array}{l}\text { Apakah dengan adanya pengawasan tersebut membuat anda termotivasi untuk } \\
\text { selalu menggunakan APD saat praktek/bekerja? }\end{array}$ & $95 \%$ & $5 \%$ \\
\hline 4 & $\begin{array}{l}\text { Jika tidak, apakah alasan anda ? } \\
\text { a. Ada tidak ada pengawas sama saja tidak menggunakan APD } \\
\text { b. Ada tidak ada pengawas selalu menggunakan APD } \\
\text { c. Tidak tahu }\end{array}$ & \multicolumn{2}{|c|}{$\begin{array}{c}5 \% \\
60 \% \\
35 \% \\
\end{array}$} \\
\hline 5 & $\begin{array}{l}\text { Kapan pegawasan dilakukan? } \\
\text { a. Setiap hari } \\
\text { b. Tidak tentu } \\
\text { c. Jika ada kejadian saja }\end{array}$ & \multicolumn{2}{|c|}{$\begin{array}{c}55 \% \\
40 \% \\
5 \%\end{array}$} \\
\hline 6 & $\begin{array}{l}\text { Siapa yang melakukan pengawasan ? } \\
\text { a. Kepala workshop } \\
\text { b. Instruktur } \\
\text { c. Tehnisi worskhop } \\
\end{array}$ & \multicolumn{2}{|c|}{$\begin{array}{l}10 \% \\
80 \% \\
10 \%\end{array}$} \\
\hline
\end{tabular}

Tabel 4.8 Jenis pertanyaan pemahaman serta penerapan aturan kerja

\begin{tabular}{|c|l|c|c|}
\hline \multirow{2}{*}{ NO } & \multicolumn{1}{|c|}{ KOLOM H } & \multicolumn{2}{c|}{$\%$ Jawaban } \\
\cline { 3 - 4 } & & Ya & Tidak \\
\hline 1 & Apakah anda perlu menggunakan APD pada saat praktek/bekerja ? & $100 \%$ & \\
\hline 2 & Apakah anda memakai APD sesuai dengan peraturan/prosedur penggunaan? & $100 \%$ & \\
\hline 3 & Apakah anda mengikuti pelatihan APD ? & $85 \%$ & \\
\hline 4 & Menurut anda kapan penggunaan APD yang tepat ? & \multicolumn{2}{|c|}{$95 \%$} \\
& a. Saat praktek/bekerja & \multicolumn{2}{|c|}{$5 \%$} \\
& b. Setelah mendapat teguran dari instruktur atau staf workshop & \multicolumn{2}{|c|}{$0 \%$} \\
\hline
\end{tabular}

Dari hasil analisa data yang diajukan dalam bentuk pertanyaan-pertanyaan (kolom $\mathrm{A}-\mathrm{H}$ ) kepada taruna, maka dapat dijelaskan sebagai berikut :

Tabel 4.1 pada Kolom A soal 1 menunjukkan bahwa seluruh taruna yang dijadikan sampel dalam penelitian ini semuanya telah mengetahui apa pengertian dari APD itu sendiri (100\%). Untuk soal no. 2 menunjukkan bahwa seluruh taruna juga telah memahami pentingnya penggunaan APD $(100 \%)$. Untuk soal no.3 menanyakan tentang apa kegunaan APD maka sebagian besar taruna sudah mengetahui kegunaan APD yaitu untuk menjaga kesehatan dan keamanan kerja (70\%) sedangan taruna yang menjawab untuk melindungi tubuh dari cedera dan sakit hanya sekitar (30\%). Untuk soal no.4 menanyakan tentang apa bahaya yang ditimbulkan jika tidak menggunakan APD. Sebagan besar taruna menjawab bahwa bahaya yang ditimbulkan jika tidak mengunakan APD adalah bisa menimbulkan kecelakaan dan gangguan kerja (95\%), sedangkan yang menjawab bahwa pekerjaan tidak dapat dilaksanakan dengan baik hanya sedikit (5\%).

Tabel 4.2 pada Kolom B soal 1 menunjukkan bahwa ruang kerja (workshop) mendukung terciptanya Keselamatan dan Kesehatan Kerja atau K3 (100\%). Untuk soal no.2 menunjukkan bahwa ruang kerja (workshop) telah terpasang poster-poster tentang K3 (100\%). Untuk soal no.3 menanyakan tentang apa saran taruna kepada institusi/pengelola workshop maka rata-rata mereka menjawab bahwa alat-alat yang rusak perlu segera diganti, juga adanya penambahan alat-alat sehingga praktek bisa berjalan dengan lancar (100\%).

Tabel 4.3 pada Kolom C soal 1 menanyakan alasan taruna menggunakan APD maka sebagian kecil taruna menjawab bahwa takut kena sanksi (5\%), sedangkan yang lainnya menjawab untuk melindungi diri dari bahaya dan kecelakaan kerja (95\%). unjukkan bahwa seluruh taruna yang 
dijadikan sampel dalam penelitian ini semuanya telah mengetahui apa pengertian dari APD itu sendiri (100\%). Untuk soal no.2 menanyakan alasan taruna tidak menggunakan APD saat bekerja, maka sebagian kecil menjawab tidak nyaman bekerja jika menggunakan APD (20\%), sedangkan yang menjawab APD tidak tersedia di workshop (75\%), dan yang menjawab sudah terbiasa tidak menggunakan APD saat bekerja (5\%). Untuk soal no.3 menanyakan sikap taruna jika APD tidak disediakan di tempat kerja (workshop), maka sebagian kecil taruna menjawab menolak untuk bekerja (5\%) sedangkan sebagian besar taruna menjawab tidak bekerja sambal menunggu APD disediakan oleh workshop (95\%).

Tabel 4.4 pada Kolom D soal 1 menanyakan apakah workshop telah menyiapkan APD sesuai dengan resiko bahaya dan jenis pekerjaan, maka sebagian besar taruna menjawab telah disiapkan (95\%) dan hanya sedikit yang menjawab tidak (5\%). Untuk soal no.2 menanyakan bahwa apakah APD mudah didapatkan, maka sebagian besar taruna menjawab mudah didapatkan (90\%) dan yang lainnya menjawab tidak mudah (10\%). Untuk soal no.3 menanyakan apakah APD cukup untuk semua taruna, maka sebagian menjawab cukup (70\%) dan yang lainnya menjawab tidak cukup (30\%). Untuk soal no.4 menanyakan apakah disediakan tempat penyimpanan APD, maka sebagian besar menjawab disediakan $(80 \%)$ dan yang lainnya menjawab tidak (20\%). Untuk soal no.5 menanyakan tentang jenis APD apa saja yang biasa digunakan dalam praktek las, maka semua taruna (100\%) menjawab 5 (lima) jenis APD dari 9 (Sembilan) jenis APD yang ada. Untuk soal no. 6 menanyakan tentang jenis APD apa saja yang biasa digunakan dalam praktek membubut, maka semua taruna $(100 \%)$ menjawab 5 (lima) jenis APD dari 7 (tujuh) jenis APD yang ada. Untuk soal no. 7 menanyakan siapa yang wajib merawat APD, maka sebaian kecil taruna menjawab adalah pihak workshop (10\%), dan sebagian besar taruna menjawab setiap taruna (90\%).

Tabel 4.5 pada Kolom E soal 1 menunjukkan bahwa sebagian besar taruna merasa nyaman menggunakan APD ketika bekerja (95\%), dan sebagian kecil tidak nyaman (5\%). Untuk soal no.2 menunjukkan bahwa APD yang digunakan taruna sudah sesuai dengan kebutuhan perlindungan dirinya (95\%) sedangkan yang menjawab tidak sesuai hanya sedikit (5\%). Untuk soal no.3 menunjukkan bahwa penggunaan APD tidak mengganggu aktifitas taruna (95\%) sedangkan yang mengganggu hanya (5\%). Untuk soal no.4 menunjukkan jawaban taruna bahwa pengunaan APD tidak menimbulkan bahaya tambahan (95\%), sedangkan yang menjawab menimbulkan bahaya tambahan hanya (5\%).

Tabel 4.6 pada Kolom F soal 1 menunjukkan bahwa di workshop terdapat aturan yang mewajibkan taruna menggunakan APD (95\%), sedangkan yang menjawab tidak ada hanya (5\%) Untuk soal no. 2 menunjukkan bahwa sebagian besar taruna sudah mengetahui adanya aturan penggunaan APD, sedangkan hanya sedikit taruna yang tidak mengetahui (5\%). Untuk soal no.3 menunjukkan sebagian besar taruna (95\%) menjawab bahwa aturan penggunaan APD membuat keselamatan dan kesehatan menjadi lebih baik, dan hanya (5\%) taruna yang menjawab tidak. Untuk soal no.4 menunjukkan hanya (40\%) taruna menjawab bahwa di workshop pernah dilakukan pelatihan $\mathrm{K} 3$, sedangkan $(60 \%)$ taruna menyatakan tidak pernah dilakukan pelatihan K3.

Tabel 4.7 pada Kolom G soal 1 menunjukkan bahwa sebagian besar taruna (90\%) memerlukan pengawasan dalam menggunakan APD dan hanya sedikit (10) yang menjawab tidak perlu. Untuk soal no.2 menunjukkan bahwa di workshop telah dilakukan pengawasan penggunaan APD saat praktek sebesar (90\%) dan (10\%) yang menjawab tidak dilakukan pengawasan penggunaan APD di workshop. Untuk soal no.3 menunjukkan bahwa dengan adanya pengawasan penggunaan APD maka taruna termotivasi untuk selalu menggunakannya sebesar (95\%), sedangkan yanb menjawab tidak sebesar (5\%). Untuk soal no.4 menunjukkan bahwa ada atau tidak ada pengawas maka taruna tetap tidak menggunakan APD sebesar (5\%) dan sebesar (60\%) menjawab bahwa ada atau tidak ada pengawas tetap menggunakan APD, sedangkan yang lainnya tidak memberikan jawaban sebesar (35\%). Untuk soal no. 5 menunjukkan bahwa pengawasan penggunaan APD dilakukan setiap hari sebesar $(55 \%)$ dan taruna yang menjawab tidak tentu sebesar (40\%), sedangkan yang menjawab nanti jika ada kejadian sebesar (5\%). Untuk soal no.6 menunjukkan bahwa yang melakukan pengawasan di workshop adalah 
kepala workshop sebesar (10\%), yang menjawab instruktur sebesar (80\%), sedangkan yang menjawab tehnisi sebesar $(10 \%)$.

Tabel 4.8 pada Kolom H soal 1 menunjukkan jawaban taruna bahwa penggunaan APD sangat diperlukan saat praktek atau bekerja sebesar (100\%) Untuk soal no.2 menunjukkan bahwa taruna menggunakan APD sesuai dengan peratur atau prosedur penggunaan sebesar (100\%). Untuk soal no.3 menunjukkan bahwa sebagian besar taruna telah mengikuti pelatihan dalam penggunaan APD sebesr (85\%) Untuk soal no.4 menunjukkan bahwa penggunaan APD yang tepat yaitu pada saat praktek atau bekerja sebesar $(95 \%)$, sedangkan yang menjawab nanti pada saat mendapat teguran dari instruktur atau staf workshop sebesar (5\%).

\section{KESIMPULAN}

Berdasarkan hasil penelitian yang telah dilakukan di workshop Politeknik Ilmu Pelayaran, maka dapat diambil beberapa kesimpulan, yaitu:

1. Fasilitas alat pelindung diri (APD) di workshop telah disediakan oleh pihak workshop dan dapat digunakan oleh taruna ataupun pasis dan dengan aman sesuai dengan yang dipersyaratkan peraturan pemerintah.

2. Persentase pemakaian alat pelindung diri yang digunakan taruna atau peserta didik lainnya dalam praktikum adalah sebagai berikut : yaitu APD masih layak digunakan sebesar $90 \%$ kategori baik, masing-masing alat pelindung diri dapat dirinci sebagai berikut : respirator yang digunakan taruna mencapai $70 \%$ kategori cukup, topi plastic mencapai $100 \%$, googles (kacamata) bubut mencapai 100\% kategori baik, sarung tangan kain 90\% kategori baik, pakaian las/apron mencapai $100 \%$ kriteria baik, sepatu karet (safety shoes) mencapai $100 \%$ (sudah dimiliki awal masuk taruna) kategori baik. Peralatan memenuhi standar minimal mencapai 80\% kategori baik, kondisi workshop memenuhi standar mencapai 85\% kateori baik, kondisi workshop terdapat symbol/isyarat keselamatan kerja mencapai 95\% kategori baik. Sebagian besar peralatan workshop termasuk alat pelindung diri yang digunakan dalam praktikum pengelasan dan membubut termasuk kategori baik dan alat pelindung diri di workshop sudah digunakan sesuai dengan yang dipersyaratkan.

3. Pengetahuan, pemahaman dan penerapan taruna terhadap APD adalah sebagai berikut :

a. Pengetahuan taruna terhadap APD sangat baik (100\%),

b. Pengetahuan taruna menyebutkan alat-alat yang termasuk APD sudah sangat baik ( $90 \%)$,

c. Pengetahuan taruna tentang kegunaan APD sudah sangat baik (100\%),

d. Pemahaman taruna akan bahaya jika tidak menggunakan APD sangat baik (100\%),

e. Penerapan penggunaan APD saat praktek sangat bagus (85\%)

f. Workshop sangat kondusif untuk penggunaan APD karena beberpa poster tentang K3 sudah terpasang dengan baik (100\%)

g. Pengawasan terhadap penggunaan APD sdh sangat baik (90\%).

\section{UCAPAN TERIMA KASIH}

Ucapan terima kasih diberikan kepada UPPM Politeknik Ilmu Pelayaran Makassar yang banyak memberikan kontribusi positif bagi penyelesaian penelitian ini termasuk didalamnya sponsor yang membiayai penelitian ini.

\section{DAFTAR PUSTAKA}

[1] Hanggraeni, Dewi, (2012), Manajemen Sumber Daya Manusia, Jakarta : Lembaga Penerbit Fakultas Ekonomi Universitas Indoensia

[2] ILO dan WHO. Joint ILO/WHO Guidelines on Health Services and HIV/AIDS. Terj.

[3] Ramli, Soehatman, (2010), Sistem Manajemen Keselamatan dan Kesehatan Kerja OHSAS 18001, Jakarta:Dian Rakyat. 
226 Syahrisal, Paulus Pongkessu, Mahadir Sirman, Heny Pasandang Nari. Penerapan Personal Protective Equipment Pada Workshop Politeknik Ilmu Pelayaran Makassar

[4] Solichin, dkk (2014), Jurnal Penerapan Personal Protective Equipment (alat Pelindung Diri) pada Laboratorium Pengelasan, Universitas Negeri Malang

[5] Arikunto, Suharsimi (2010), Prosedur Penelitian Suatu Pendekatan Praktek, Jakarta: PT.Rineka Cipta.

[6] Sugiyono (2011), Metode Penelitian Kuantitatif, Kualitatif dan R \& D, Bandung: Alfabeta

[7] Astrid Sulistomo, Seminar K3RS, 2001

[8] Permenaker, (2010), Alat Pelindung Diri, Jakarta, Menteri Tenaga Kerja dan Transmigrasi Republik Indonesia.

[9] Suma'mur, (1989), Keselamatan Kerja dan Pencegahan Kecelakaan, Jakarta

[10] Surat Kabar Kompas (17 September 2002) Kasus Kecelakaan Kerja di Indoensia

[11] Tim Worskhop (2000), Kejadian Kecelakaan kerja actual di workshop

[12] Tim Worskhop (2019), Kejadian Kecelakaan kerja actual di workshop

[13] Zulmiar Yanri et al., Pedoman Bersama ILO/WHO tentang Pelayanan Kesehatan dan HIV/AIDS. Jakarta: Depankertrans RI, 2005.http://www.who.int/hiv/pub/guidelines/who_ilo_guidelines_indonesian.pdf Diakses: 24 Juni 2010. 